\title{
Prevalence Of Sexual Harassment Among Sportswomen In Pakistan
}

\author{
Shagufta Jahangir \\ \& \\ Asma Manzoor \\ Women Studies \\ University of Karachi
}

\begin{abstract}
Sexual harassment $(\mathrm{SH})$ in sports is present in all over the world due to socially constructed values, myths and norms. Harassment is faced by large number of women in sports and it is present in all individual and team sports. The ratio is less in South Asian region as compared to western countries and it is also present in Pakistan. The objective of the research is to explore the social behaviors with the victimized sports women of SH in the Pakistani society. The researcher has used non-probability method in which purposive sampling method is used to collect data through interview schedule from 210 sports women residing in different places of Pakistan. Findings of the study highlights that sport women face SH. According to sports women they are harassed or abused by their male counterparts, i.e. which are their trainers, coaches and lower staff even during travelling for their sports seasons. The results of SH showed that women left sports due to the social norms of the society. Women hide such incidents due to the sake of self-respect, self-esteem and family honor. It is observed that women who faced SH usually attempt suicide to protect their honor. As a result, these women fear and hate men and they face psychological issues. This article aims to describe that $\mathrm{SH}$ is present in sports in Pakistan like other countries and females are aware about it, because usually in Pakistani society such cases are kept hidden. The importance of this study is to aware women about SH so that they can safeguard themselves.
\end{abstract}

Keywords: Sexual Harassment, Abuse, Sport, Oppression, Discrimination, Socially Constructed Values.

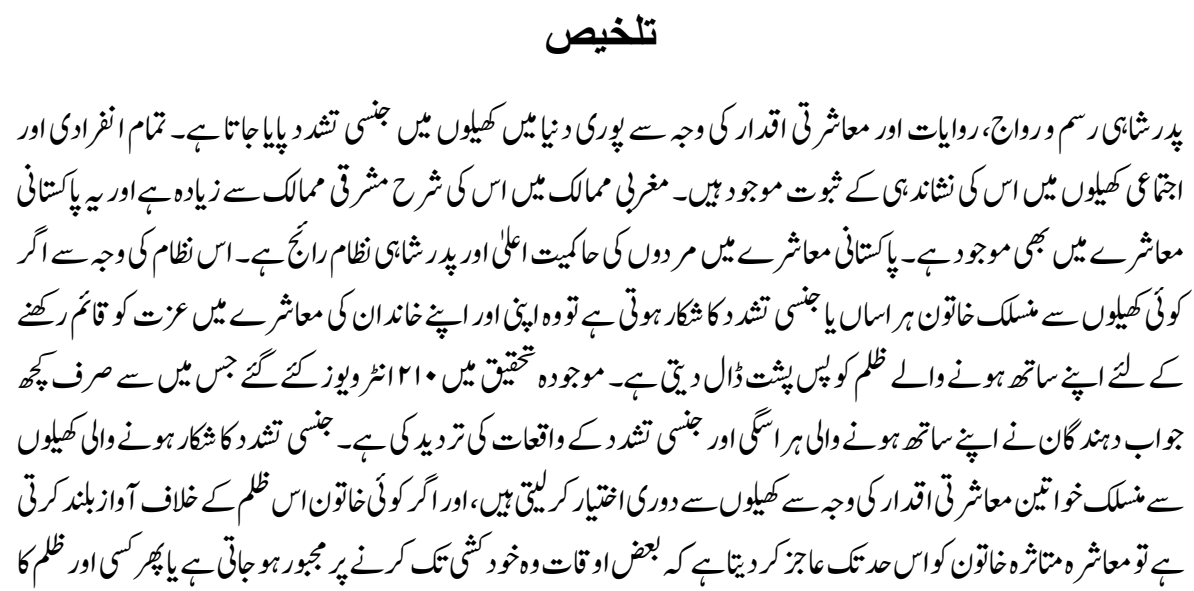




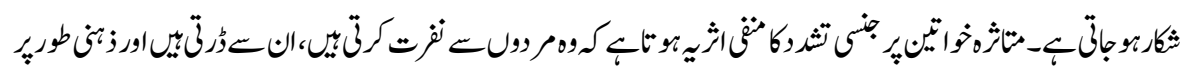

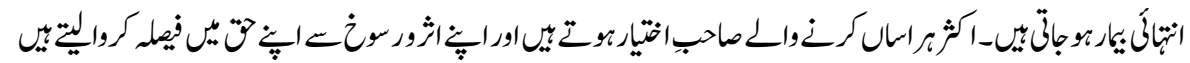

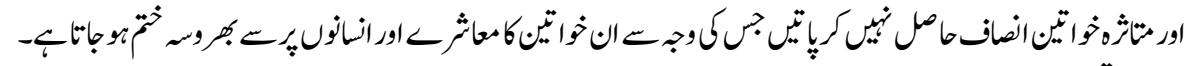

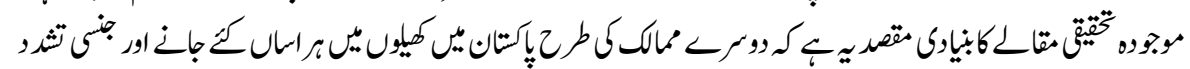

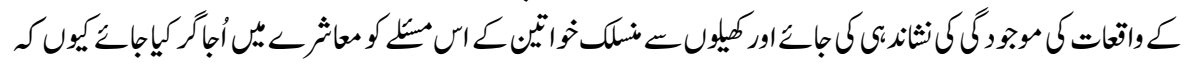

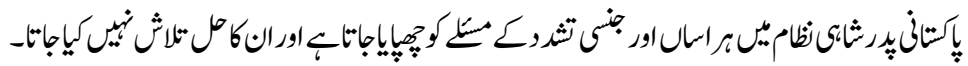

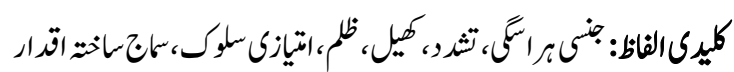

\section{Introduction}

Sexual harassment prevails at work place and at educational institutions (Stockdale, 1996), and extensive research has shown that in the last three decades it is observed in sports also (Fasting et al., 2004). Harassment persists in sports field also but very few researches have been conducted on sexual harassment on sports women before 1980s (Toftegaard Nielsen, J. 2001). During the mid-1980's, it became an alarming issue for trainers and sports persons (Brackenridge C, 2001). The first research article regarding SH with sports women was published in late 1980's (Crosset, 1986 \& Brackenridge, 1987). In 1980s exploitation and sexual harassment against sports women became very common (Fasting et al., 2002).

The prevalence rate of sexual harassment is between 2 to 50 percent globally and it varies country to country based on their culture and values (Vanden Auweele et al., 2008). About $90 \%$ of victims suffer from emotional stress (Garlick, 1994), the effects of sexual harassment are very long term and lifelong. In the sports arena men are considered as dominant while women still have the subordinate position; therefore, the chances of sexual harassment automatically increases (Quina, 1991). Globally the trend is seen that women are considered as an entity and men show sexist attitude (Curry, 1991).

Journal of Sexual Aggression (JSA) organized a symposium on sexual harassment in Sports, which was held at the $\mathrm{X}^{\text {th }}$ Congress of the International Society of Sports Psychology, Greece from $28^{\text {th }}$ to $2^{\text {nd }}$ June 2001 . The main purpose of that symposium was to find out the causes of sexual harassment in sports and increase the awareness of sexual abuse against women and children. About more than 60 committees are working to protect teenagers, young people and females in sport across the globe. In America, sports women face more sexual harassment (Volkwein, 1997). Whereas, in Canada, even Olympian coaches, were found involved in sexual harassment with sports women, as per observations six times more than others (Kirby, \& Greaves, 1996), and almost 1.5 percent sports women face the abuse and sexual harassment (Annmarie Pinarski, 2000). In Australia the elite sports players face sexual harassment and abuse, where no action is taken against these cases (Leahy et al., 2002). 
Sports organizations are responsible to create a code of morals and behavior for trainers to promote an atmosphere where the cases of sexual harassment and exploitation can be dealt in an appropriate manner. These organizations are also responsible to develop selfsufficiency among sports women by introducing trainer teaching programs through the integration of the subjects of sexual harassment, violence and abuse. They also suggested that there must be certain criteria for the selection of every employee. The researches on sexual harassment in sport have inclined to take an extra organizational tactic, because only few people are acknowledged about the characteristics, reasons, consequences and manifestation of sexual harassment in sports to raise the awareness level. Sports organizations and sports science describe that the presence of sexual harassment in sports is due to gender ratio; sexualized atmospheres and organizational power.

Sports field is considered as an unsafe environment for sports women due to sexual harassment and abuse, it is being reported that authorities are involved in such activities (Fasting $\mathrm{K}$ et al, 2003). Every government is responsible to provide protection and rights to avoid gender discrimination, religious barriers, ethnicity issues and class difference (Moghadam, 2002).

The basic barriers for women to participate in sports are involved religion, socially constructed values, male domination, dress code, gender discrimination, patriarchy and limited resources (Dagkas et al., 2010). After 2012, besides all social problems a revolution has begun internationally for the sake of sports women. 2012 was declared as the women's year, because all the nations accepted two nations (South Sudan and Vatican) sent their women to contribute in Olympics games (polgeonow, 2012). The trend shows that still sports women have to face barriers like gender discrimination, ethnicity, traditions, norms, civilization, culture, race, nationality, political views, and religion. To bring everything in order it is very important to increase the participation of women in sports, and for all the nations should stand together to liberate women in all fields.

Usually the perpetrators of $\mathrm{SH}$ are dominant positions and have power to keep sports women are victimized and keep silence (Marks, 2016). Sports women do not reported the cases to the concerned authorities due to the fear of drop out from the team, even colleagues do not believed about the harassment incidence and feel embarrassed in front of coach or team (Fasting, 2014). Carroll (1993) pointed out that men show their dominancy through the act of violence. It is essential to increase the women's participation in sports for eradicating the male dominancy and SH (Brackenridge, 2001). Sports women can protect her from SH as they have empowerment, self- confidence and sagacity of physical proficiency (Bart, 1981). According to Fasting (2014) perpetrators of SH do not get punishment of their sin due to the victims fear. In Pakistan many cases are highlighted but due to the strong relationship of perpetrators with the enforcement agencies and no charges dueled on them (Sameyah Said, 2017; Dunya News channel, Abtak News TV, Samaa TV. 2017; Shamsi, Rahim Amber, 2014). 
Indian sports women are also victimized of SH. A famous Indian cricketer of 1981- 1986 and a very well known hockey player pointed out that $\mathrm{SH}$ is present in Indian Women Cricket team. According to each player that the dreadful thing about India is that authentic brilliant and meticulous players do not welcome and get penalized for not giving sexual favor (Verma et al., 2015). In Pakistan a hockey player had claimed the sexual harassment to the coach and her colleagues provided eye witness against the coach but due to unfair investigation of both the players were suspended for life time from the Pakistan Hockey Federation (PHF) (Sameyah Said, 2017, Dunya News channel, Abtak News TV, Samaa TV, 2017). According to (Shamsi, Rahim Amber, 2014) that harassment and abuse attitude of coach, injustices stance and wrong allegations compelled a cricketer in 2014 for suicide. Coaches are enjoying and players lost their careers as well as their dignity in the society so these live examples prohibited women from sports in Pakistan because society not supports to the women to move over men (Sameyah Said, 2017; Shamsi, Rahim Amber, 2014). SH is present in Pakistan in all sports but social behaviors preventing women to report it because victims never punished in Pakistan. Timmermann (1999) and Whelehan, (1995) observes that this issue is more complicated in other countries as compared to Pakistan. According to Jamshed Kazi (Representative of UN Women Pakistan, 2016) explored that the key challenged for Pakistani sports women is a safe public place where they play without facing any kind of harassment (Esapzai, 2014). Men are occupied administrative and coaching positions in the women sports federation's even men on authority of decision making on sports women issues. Women are powerless regarding her own issues so men get benefits from this weakness and just pass the orders without taking favor for women so $\mathrm{SH}$ in sports is increasing day by day in Pakistan.

\section{Objectives}

Discussion on the SH is taboo in the Pakistani society especially with the reference of women. The main theme of the study is to showing the social behavior with the victimizers and exposed the perpetrator for saving the future of youths from $\mathrm{SH}$.

- To analyze the social behaviors with the victimized sportswomen of SH during their professional career.

- To find out that the rate of prevalence of SH with sports women in the Pakistani society.

- To explore that usually in Pakistan the victimized sport women are face more SH during the struggle of justice and the perpetrators escapes from allegations.

\section{Review Literature}

Sports are physical activities in which players get involved in many games including cricket, tennis polo and so on. As SH and abuse is present in all sports (Fasting et al., 2004). It is nearby at all levels (Brackenridge, 1994). Fasting (2014) also pointed out that the prevalence rate of sexual harassment is ranging 2 to $50 \%$ globally and it varies country to country based on their culture and values. At present very limited investigations there are available about $\mathrm{SH}$ in sports (Marks S, 2016). According to 
United Nations (2007) report that the rate of SH in sports in Canada (40 - 50\%), Australia $(31 \%)$, Norway (28\%), Denmark (25\%) and in Czech Republic is $(45 \%)$. This report clearly shows that the prevalence rate of SH is present in almost countries with fluctuating rate. According to Fasting (2014) the study on sports students of USA shows $19 \% \mathrm{SH}, 21 \%$ United Kingdom club athletes faces SH, in Turkey a study shows that 200 sports women out of 365 are victimized of SH, it means that the prevalence rate of SH is $65 \%$, Danish sports sciences students offending 25\% SH, even a study (1200 sports women) of $\mathrm{SH}$ in Canada pointed out that very high profile $(22 \%)$ sports women of Olympics accepted that they had sexual relations with authority persons while 9\% accepted that they had sexual relations. Fasting (2014) also point out that a study of 2118 sports women of Australia showed that $31 \%$ of women were victimized of SH and $41 \%$ abused through sports surroundings. The First World Conference held in 1996 at Lausanne (Switzerland) in which participant countries agreed to solve the sports women issues including sexual harassment. In the second world conference in 2000 at Paris (France), where finalized they to give equal opportunities without gender discrimination among men and women to handle their issues without involvement of men.

\section{Figure-1: Social effects of Sexual Harassment on Sports Women}

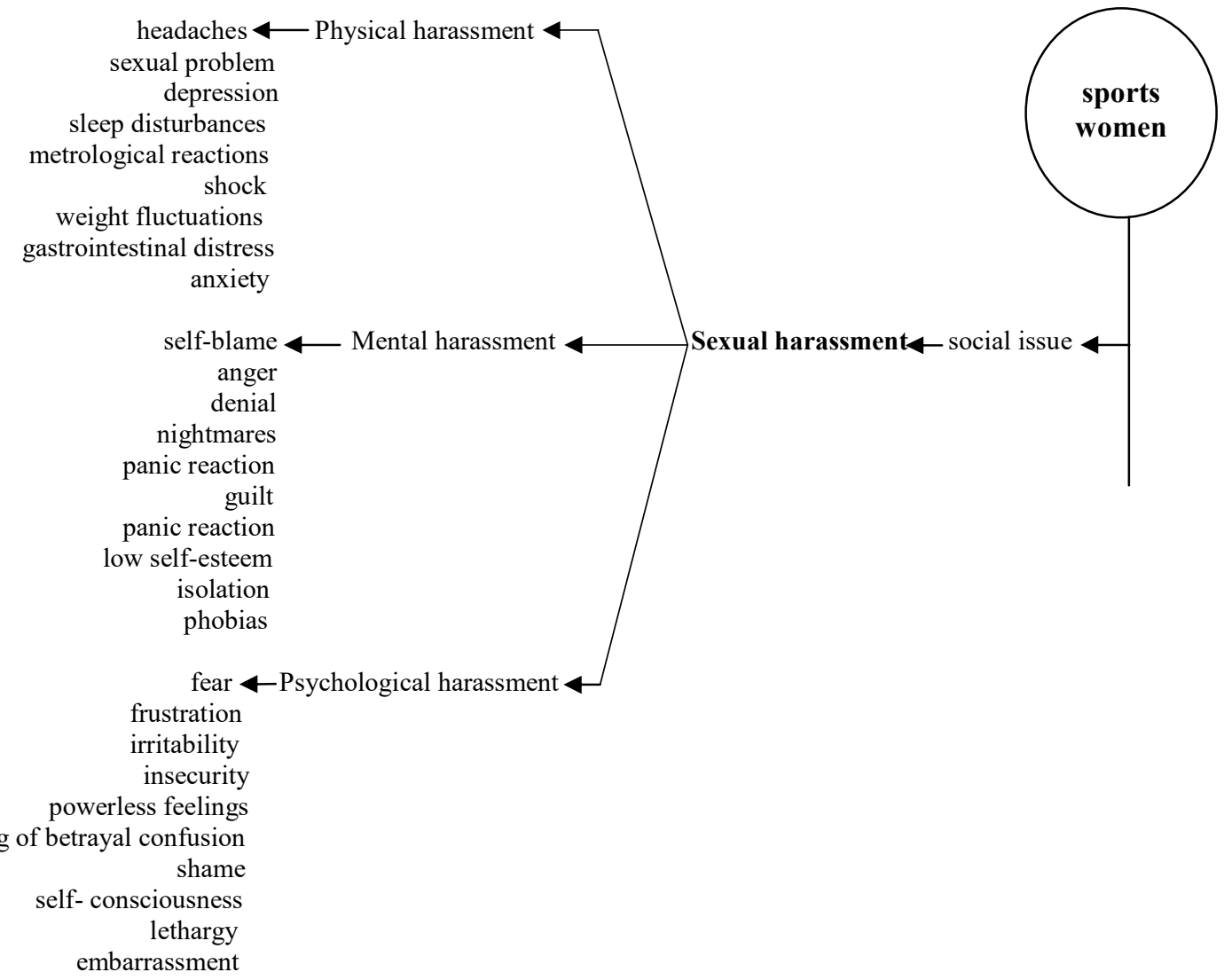


Victims of SH are physically, mentally, spiritually, emotionally, and psychologically very upset (Hillberg T, 2011; Garlick, 1994). According to (Koss, 1991) point out that $21-81 \%$ females are mentally, physically and emotionally disturbed regarding sex. Physically victims of SH have weak in general health, reproductive health, cardiopulmonary health and gastrointestinal in any stage of her/his life (Irish et al., 2010) even according to (Waldron ., et al 2011) some time victims die. Fasting (2014) described that victims face anxiety, feel helplessness, fear of rape, poor performance, depression, less confidence, feel guilt and disturbed family life.

With the reference of Pakistan, very limited literature available on SH regarding women in sports due to the reason, it is impossible to investigate thoroughly. Social myths, norms, customs and traditions of Pakistan strictly prohibited sports women to show the real picture of SH in front of public because the social values, victims are responsible for every wrong and have no support from anywhere even of her family. Victimized woman / girl have become sensitive. It is too much difficult for the researcher to find out from any sports women. According to (Shamsi Rahim and Esapzai, 2014) that a female cricketer in 2014 attempt suicide due to the SH so whenever asked about SH to sports women especially to those who are the victims of these brutal acts of SH then they keep silence. Some sports women highlighted that their name must be kept secret or do not disclosed in public, while they were sharing harassment incidence with researcher. In Pakistan cases of SH with sports women are reported and media is also highlighted but the powerful perpetrator use their power and victims back out from their cases due to fear. Influential and non-serious attitude of the society is also a main contributing factor to hide this serious issue.

Figure-2: Shows the prevalence of SH in different sports in Pakistan

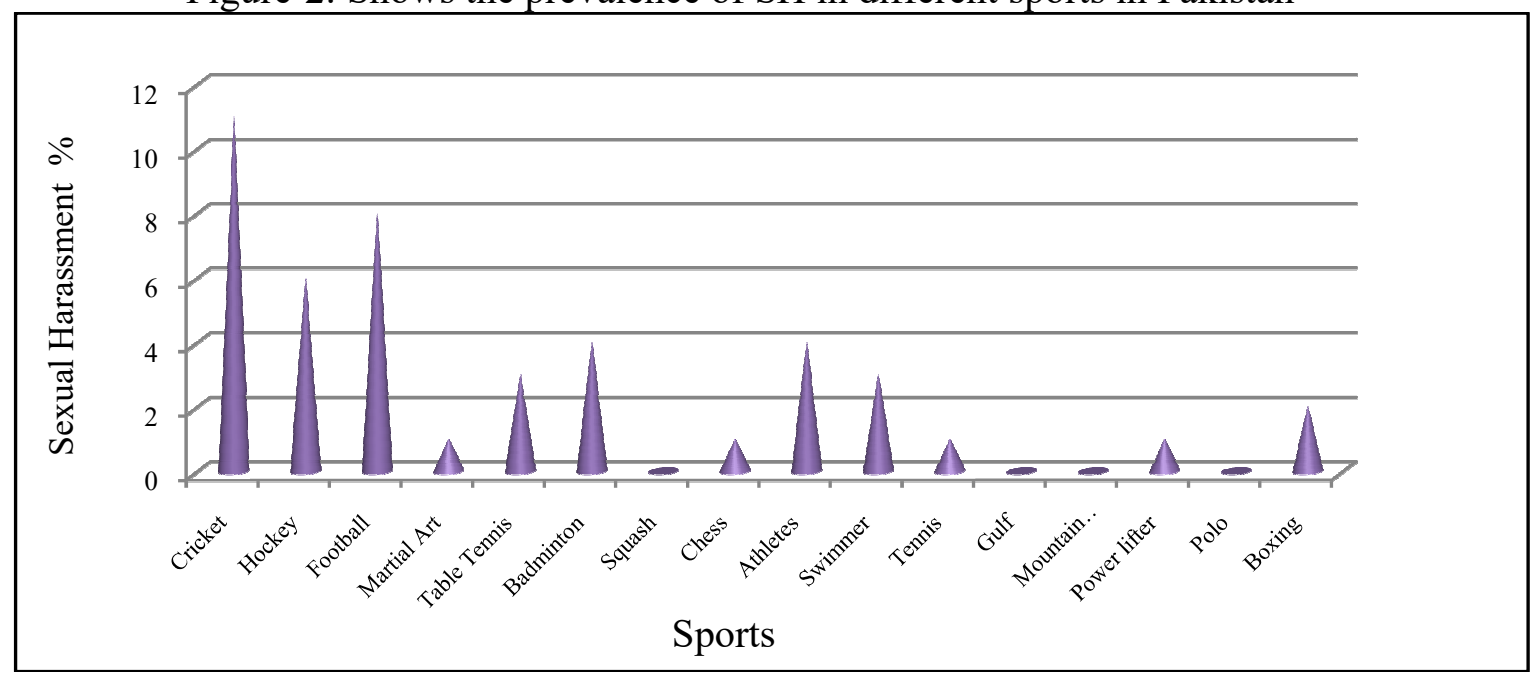

Source: Researcher. 
According to (Henriette Bjoerge and Faria Salaman, 2016) that in Pakistan, it is the key challenge for women and girls in sports is the lack of safe public space making it difficult to find places to play sports activities without facing harassment or abused. It means that $\mathrm{SH}$ is increase day by day in the society. It is a major impediment in bringing the best players to the fore. It is noted that incompetent players are exploited sexually either by will or by force in the wake of achieving favors and influential positions.

\section{Methodology}

The researcher has used non-probability method in which purposive sampling method is used to collect data through interview schedule from 210 sports women residing in different places of Pakistan with review of global literature. They are all in the age bracket of between 11 to 41 years. All of the participants belong to different individual and team sports. Almost all the interviews conducted at respondents practice place, home, universities, federations, clubs or cafeteria. Approximately 109 interviews were conducted through direct communication. 41, were done after sending letters to the different sports federations while 23, were conducted by telephonic communication. 19, questionnaires are filled through the federations and were sent back to the researcher via mailing address like mountain climber. 18 interviews were done through other sources (personal relations). An interview completed approximately 40 to 50 minutes. The interview of the Scuba diver (Rosheen Khan) done through a telephone call. Almost interviews of swimmers were being taken at the Karachi Gym khana during $16^{\text {th }}$ National Women Junior Age Group Swimming Championship April $9 \& 10,2016$ and $29^{\text {th }} \& 30^{\text {th }}$ October 2016. The women have been engaged in cricket $(n=35)$, hockey $(n=27)$, football $(n=23)$, martial art $(n=15)$, table tennis $(n=10)$, badminton $(n=13)$, squash $(n=03)$, chess $(n=05)$, athletes $(n=29)$, Swimmer $(n=26)$, Tennis $(n=05)$, Golf $(n=02)$, Mountain climber $(\mathrm{n}=02)$, Power lifter $(\mathrm{n}=03)$, Scuba diving $(\mathrm{n}=02)$ and Boxing $(\mathrm{n}=10)$. The participants are playing in national and international competitions and Olympics. Some participants are the iconic and explore the name of Pakistan internationally. Minichiello et al., (1997) argue that through semi-structured interview researcher observed the daily routine of a respondent.

\section{Results \& Discussions}

There are 67 sportswomen out of 210 reported of incidents of practice of SH from their coaches' managers, team selector and other profession related males. Victims are in between the age of 15 to 36 . Almost victims are leaved their sports activities due to sexual harassment, threatened and intimidated. The finding shows that only $31.9 \%$ sportswomen accepted that they face this issue. Presented data shows that sports women described that some males need unwanted sexual attachment and discussing about her bodies. A sports girl (cricketer) told that a coach told me that if I sit with him very closely 
then he promoted me nationally and internationally. My place is conformed in the team constantly. Loose talk, dirty comments, discussing about the sexual parts of the women body, unwanted sexual hints, requests for sexual favors, unwelcome sexual advances, laughing, pinching, fondling, jokes, looks, comments, touching are quite common from the coaches and managers. Coaches are playing the vital role in an athlete's sports life because they decided the position of player, playing time, grants, scholarship amount and opportunities of playing in the team. Coaches have the power to up or down the status of player even they involved the sports attire, food, rest hours and even membership in an organization or fraternity. Furthermore; coaches and players frequently attach in physical contact for learning the techniques and tactics of playing. Sometime player's dependent too much to the coaches and this is also a reason of SH with sports women.

Table: 1

Distribution of respondents according to attitudes of male coaches during training

\begin{tabular}{|l|c|c|}
\hline Attitudes of male coaches during training & Frequency & Percentage \\
\hline Good & 03 & $1.428 \%$ \\
\hline Harassment & $\mathbf{9 3}$ & $\mathbf{4 4 . 2 8 5 \%}$ \\
\hline Normal & 24 & $11.428 \%$ \\
\hline Professional & 90 & $42.857 \%$ \\
\hline Total & $\mathbf{2 1 0}$ & $\mathbf{1 0 0 \%}$ \\
\hline
\end{tabular}

Data indicated that $44.285 \%$ respondents reported that the coaches harass player's especially young and inexperienced girls whereas $42.857 \%$ respondents said that the attitude of coaches to the sports women is purely professional, whereas respondents said that during training $11.428 \%$ respondents described that the attitude of coaches are normal during training, while $1.428 \%$ respondents reported that the attitudes of male coaches are very good (Table: 1 ).

Table: 2

Distribution of respondents according to attitude of staff during trainings/ competitions

\begin{tabular}{|l|c|c|}
\hline Attitude of male staff, during trainings / competitions & Frequency & Percentage \\
\hline Normal & 133 & $63.332 \%$ \\
\hline Good & 35 & $16.666 \%$ \\
\hline Professional & 28 & $13.332 \%$ \\
\hline Harassment & $\mathbf{1 4}$ & $\mathbf{6 . 7 1 1 \%}$ \\
\hline Total & $\mathbf{2 1 0}$ & $\mathbf{1 0 0 \%}$ \\
\hline
\end{tabular}

Data indicated that $63.333 \%$ respondents reported that the attitude of staff (other than coaches) during training and competitions is usually normal. $16.666 \%$ reported that they are extremely very good. $13.333 \%$ said that it is professional, $5.238 \%$ said that it has 
been unexpected. While $1.428 \%$ reported that the attitude of staff during training / competitions has harassed them a lot (Table: 2 ).

Table: 3

Distribution of respondents according to the attitude of common man

\begin{tabular}{|l|c|c|}
\hline Attitude of common man & Frequency & Percentage \\
\hline Insulting behavior & 37 & $17.619 \%$ \\
\hline Misbehavior & 21 & $10.00 \%$ \\
\hline Harassment & 67 & $31.904 \%$ \\
\hline Offering friendship & 85 & $40.476 \%$ \\
\hline Total & $\mathbf{2 1 0}$ & $\mathbf{1 0 0 \%}$ \\
\hline
\end{tabular}

The data identifies that $40.476 \%$ of the respondents reported that males usually offer friendship just for the sake of fun, whereas $31.904 \%$ male harass and abuse players while $17.619 \%$ respondents reported that males of the society have shown insulting behavior towards them and $10.00 \%$ said that males misbehaved with them (Table: 3 ).

Table: 4

Distribution of respondents according to the myths and norms regarding women sports

\begin{tabular}{|l|c|c|}
\hline Myths and norms regarding women sports & Frequency & Percentage \\
\hline Society prohibited & 87 & $41.428 \%$ \\
\hline Religion prohibited & 70 & $33.333 \%$ \\
\hline Revolt & 09 & $4.285 \%$ \\
\hline Become independent & 05 & $2.380 \%$ \\
\hline Girls do not listen to their parents & 39 & $18.571 \%$ \\
\hline Total & $\mathbf{2 1 0}$ & $\mathbf{1 0 0 \%}$ \\
\hline
\end{tabular}

In this table $41.428 \%$ respondent's said that the society strictly prohibited women from participating in sports activities due to its strong patriarchal setup, according to the views of $33.333 \%$ religion prohibited them to participate in sports and $18.571 \%$ respondents have described that society supposed that sports women / girls do not listen to their parents while $4.285 \%$ respondents have a very strong point of view that those who participated in sports activities usually revolt from their norms and values and disobey their parents and they do not follow the socially constructed values and enter in sports, whereas, $2.382 \%$ reported that they become more independent and make their own decisions in life (Table: 4). 
Table: 5

Distribution of respondents according to sports women accepted in the society

\begin{tabular}{|l|c|c|}
\hline Sports women accepted in the society & Frequency & Percentages \\
\hline Yes & 07 & $3.333 \%$ \\
\hline No & 143 & $68.095 \%$ \\
\hline Depend on girls status (socio-economic) & 17 & $8.095 \%$ \\
\hline Currently accepted & 43 & $20.476 \%$ \\
\hline Total & $\mathbf{2 1 0}$ & $\mathbf{1 0 0 \%}$ \\
\hline
\end{tabular}

Data in the above table shows that $68.095 \%$ respondent's said that sports women are not being accepted by the society, whereas $20.476 \%$ respondents said that currently sports women's are easily accepted in Pakistani society while $8.095 \%$ said that the socioeconomic status of women / girls plays an important role in their participation in sports activities, whereas only $3.33 \%$ sports women have been easily accepted by the society as an sports women (Table: 5).

Sports women/girl highlighted the consequences that some coaches and managers appearance all pure Islamic such as dress code, piousness, piety are asserting and pretending to be pious but they do practiced harassment with the sports women. A girl told that:

"A coach gives open offer to girls for sexual favor then them putting them on the regional and international teams".

Another sports girl described that:

"When I entered in this field then some elder players told me the name of some people and harshly advised me to reserves from those particular persons and leave specific distance with them physically".

Few elder and experienced sports women reported that just for the sake of their position some ladies give opportunity to coaches, managers and selector to used young girls. Sexual harassment is also depends on sports women economic and social status. A reported case of suicide by a female cricketer was due to $\mathrm{SH}$. The financial status of this victimized girl was very weak and her relatives were not able to fight legally against the perpetrator (coach) and exposed true picture of the case of SH and in last girl player attempt suicide. It means that if player belong to low socio economic status then she is probably has more chances of SH rather the strong socio-economic status

Some sports women pointed out that SH also depend on the sports, like cricket, football, and hockey have more chances of SH rather swimming, chess and gulf. Other sportswomen told that touching is strictly prohibited according to International Law but some coaches try to touch women players and taking advantage. Sometime other female's colleague pressures new comers to give sexual favor to their coaches and managers. 
It is very hard for Pakistani women to play sports as women due to social values. It is really a huge accomplishment for women in Pakistan to achieve the higher level of status in sports. From the birth of Pakistan, it has been representing many iconic sportswomen. In Pakistan sports for women changed gradually even there is lack of support for women in sports. Women play sports just for fun without chosen as profession. Social issues, cultural barriers, poverty, lack of access to education are hindering women from sports and they are unable to fulfill their dreams but according to available literature sports women family play vital role for exposure of women in any sports. Some have even travelled alone by using public transportation. The main finding of the data is that $\mathrm{SH}$ is present in all sports but due to the social behaviors, Pakistani sportswomen hide it and leave the sports even in some cases they attempt suicide and finished their lives.

\section{Conclusions}

The prevalence of $\mathrm{SH}$ is present in sports of Pakistan in all individual and team sports. The socially constructed values, patriarchal society, Socio - economic status, Gender discrimination and male dominancy are restricted women's to open their lips on this crucial issue. The ratio of $\mathrm{SH}$ is more than the consequences. Due to the perpetrators position and socio-economic status very bold and talented sports women's are also neglecting to talk about this brutal issue and some sports women talk about it but with very fear.

\section{Recommendations}

1. It is recommended to provide awareness in the society about the basic social, human and religious rights of women.

2. Remove the gender stereotyping of women from the society.

3. Develop the women friendly environment of management and executive infrastructure in which women are responsible for all activities.

4. Leadership and key posts of the sports federations occupied by men and women are hesitating to share their problems (harassment issues) to men so leadership is given to the women.

5. Sports Minister allocates a person (female) who should responsible to directly taking care of girl's during sports activities and if any event (abuse or sexual harassment) is occur then women / girls reported it without any dread of adverse penalty.

6. Secure women from religious extremist and terrorist due to the issue of terrorism in Pakistan.

7. Try to provide female coaches to sportswomen but if male coaches are provide, it be sure that they are be aware about the relationship between women and coaches because almost sexual issues are comes from the coaches. 
8. Media (T.V, newspaper, magazines) should give positive coverage to women sports and live telecast should exist during national and international competitions without enhancing the only sexual parts of women.

\section{References}

Abtak News TV. (2017). Harassment Scandal Hockey Team Players Iqra Javed Speaks up for Syeda Sadia. Retrieved from: https://abbtakk.tv/en/harassment-scandalhockey-team-player-iqra-javed-speaks-up-for-syeda-sadia/ on 21-10-2017.

Annmarie Pinarski, (2000). Note, When Coaches "Cross the Line": Hostile Athletic Environment.

Australian Sports Commission. (2001). Pregnancy in Sport-Forum Outcomes. Sydney. Available from: http://www.ausport.gov.au/women/ forum.asp.

Bart, P.B. (198). A study of women who were both raped and avoided rape.Journal of social issues, 37(4), 123-137

Brackenridge, C.H. (1987) 'Ethical problems in women's sport', Coaching Focus Leeds: National Coaching Foundation, Summer, vol.6, pp.5-7.

Brackenridge CH. (1994). Fair Play or Fair Game: Child Sexual Abuse in Sport. Int RevSociol Sport, vol.29, pp.287-99.

Brackenridge, C.H. (2001). Spoilsports: Understanding and Preventing Sexual Exploitation in Sports. Florence, Italy, UNICEF Innocenti Research Centre.

Carroll, B. (1993). Factors Influencing Ethnic Minority Groups' Participation in Sport. Physical Education Review, vol.16:1, pp.55-66.

Crosset, T. (1986). Male Coach-Female Athlete Relationships. Paper Presented at the First Interdisciplinary Conference for Sport Sciences, Sole, Norway, November 15-16.

Curry, T.J. (1991). Fraternal Bonding in the Locker Room: A Pro Feminist Analysis of Talk about Competition and Women. Sociology of Sport Journal, vol.8, pp.119-135.

Dagkas, Symeon \& Tansin, Benn (2010). Young Muslim Women's Experiences of Islam and Physical Education in Greece and Britain: A Comparative Study. Sport, Education \& Society, 11.1 (2006): 21-38. 
Dunya News TV. (2017). Harassment Scandal: Iqra Javed Speaks up for ex Women's Hockey Team Goalkeeper, retrieved from: http://dunyanews.tv/en/Sports/410619Harassment-scandal:-Iqra-Javed-speaks-up-for-Syeda-Sadia on 21-10-2017.

Esapzai, Samar. (2014). Can a Woman in Pakistan Play Sports without Being Sexually Harassed? The Express Tribune. Retrieved from: http://www.tribune.com.pk on March 10,2013.

Fasting, K. (2014). Women and Sports, Scientific report series, Issue 1.4, pg 1-11.

Fasting, K., Brackenridge, C. \& Sundgot - Borgen, J. (2004). Prevalence of Sexual Harassment among Norwegian Female Elite Athletes in Relation to Sport Type, International Review for the Sociology of Sport, vol.39:4, pp.373-386.

Fasting, K., Brackenridge, C. \& Sundgot Borgen, J. (2003). Experiences of Sexual Harassment and abuse amongst Norwegian Elite Female Athletes and NonAthletes, Research Quarterly for Exercise and Sport, vol.74:1, pp.74-97.

Fasting, K., Brackenridge, C. \& Walseth, K. (2002). Consequences of SH in Sport for Female Athletes. The Journal of Sexual of Sexual Agression, vol.8:2, pp.37-48.

Garlick, R. (1994). Male \& Female Responses to Ambiguous Instructor Behaviours. Sex Roles, vol.30, pp.135-158.

Hargreaves, J. \& Vertinsky, P. (2007). Physical Culture, Power and the Body. London \& New York: Routledge.

Henriette Bjoerge \& Faria Salman. (2007). United Nation Asian and the pacific, football changing young women's lives in Pakistan

Hillberg T, Hamilton-Giachritsis C, Dixon L. (2011). Review of Meta-Analyses on the Association between Child Sexual Abuse and Adult Mental Health Difficulties: A Systematic Approach. Trauma Violence Abuse 2011; 12:38-49.

Hollway, W. (1996) Gender and Power in Organizations. In B. Fawcett, B. Featherstone, Hearn J. IN ADDITION, C. Toft (Eds) Violence and Gender Relations: Theories and Interventions. London: Sage.

http://www.polgeonow.com/2012/07/which-countries-not-in-olympics-london-2012.html retrieved on 23-01-2018. 
Irish, L., Kobayashi I, Delahanty DL. (2010). Long-Term Physical Health Consequences of Childhood Sexual Abuse: A Meta-Analytic Review. J Pediatr Psychol; vol.35, pp.450-61.

Kirby, S. \& Greaves, L. (1996). Foul Play: Sexual Abuse and Harassment in Sports. Paper Presented to the Pre-Olympics Scientific Congress, Dallas, USA on Women and Sport.

Leahy, T., Pretty, G. \& Tenenbaum, G. (2002). Prevalence of Sexual Abuse in Organized Competitive Sport in Australia', Journal of Sexual Aggression, vol.8:2, pp.16-36.

Lenskyj, H. (1992b). Unsafe at Home Base: Women's Experiences of Sexual Harassment in University Sport and Physical Education. Women in Sport and Physical Activity Journal, vol.1:1, pp.19-34.

Marks S, Mountjoy M. \& Marcus M. (2016). Sexual Harassment and Abuse in Sports: The Role of the Team Doctor, http://bjsm.bmj.com/ on January 22, 2016 Published by group.bmj.com

McGregor, M. (1998) Harassment and Abuse in Sport and Recreation. CAHPERD Journal de L'Acsepld, summer, vol.64:2, pp.4-13.

Minichiello, V., Aroni, R., Timewell, E. \& Alexander, L. (1997). In-Depth Interviewing - Principles, Techniques, Analysis (2nd Ed.). South Melbourne: Addison Wesley Longman Australia.

Moghadam, V. (2002). Islamic Feminism and its Discontents: Toward a Resolution of the Debate Signs. Journal of women in Culture and Society, vol. 27:1, pp.135-70.

Quina, K. (1991). The Victimization of Women. In M.A. Paludi (ed) Ivory Power. Sexual Harassment on Campus. Albany, NY: State University of New York Press.

Rupali A. Ingole. (2015). Women and Sports in India, Edunous International Peer Reviewed Journal of Interdisciplinary Education, vol.1:2.

Samaa, TV. (2017). Reject Harassment Claim, Slaps Players with Indefinite Suspension. Retrieved from: https:/www.samaa.tv/sports/2017/10/phf-rejects-harassmentclaim-slaps-players-with-indefinite-suspension on 21-10-2017. 
Sameyah Said (2017). Former Hockey Team Goalkeeper to Pursue Harassment Case Alone after PHF Shuts its Doors, Retrieved from: https://www.com/news/1365938 on December 10, 2017.

Shamsi, Rahim Amber. (2014). Why Haleema Rafique's Death Shpuld Matter and Why it Won't. Daily DAWN Newspaper, July-17'2015, retrieved from: http://www.dailydawn.com.pk, file://E:/HARASSMENT/Teenage $\%$ crickter $\% 20$ Halima\%Rafique\%20dies\%20und\%mysterious\%20circumstances\%20-\%Pakistan\% 20-\%20DAWN.COM.html.

Stockdale, M.S. (1996). Sexual Harassment in the Workplace. Perspectives, Frontiers and Response Strategies. Thousand Oak, CA: Sage.

Timmermann, G. \& Bagemer, C. (1999). Sexual Harassment in Northwest Europe. The European Journal of Women Studies, vol.6, pp.419-439.

Toftegaard Nielsen, J. (2001). The Forbidden Zone: Intimacy, Sexual Relations and Misconduct in the Relationship between Coaches and Athletes. International Review for the Sociology of Sport, vol.36:2, pp.165-183.

Toftegaard Nielsen, J. (1998) The Forbidden Zone: Intimacy, Sexual Relations and Misconduct in the Relationship between Coaches and Athletes. Unpublished Master's Thesis, Department of Sport, University of Copenhagen.

United Nations. (2007). Women, Gender Equality Sport. Women 2000 and beyond. Published to Promote the Goals of the Beijing Declaration and the Platform for Action. Division for the Advancement of Women Department of Economic and Social Affairs.

Vanden Auweele, Y., Opdenacker, J., Vertommen, T., Boen, F., Van Niekerk, L., DeMartelaer, K., et al. (2008). Unwanted Sexual Experiences in Sport: Perceptions and Reported Prevalence among Flemish Female Student-Athletes. International Journal of Sport \& Exercise Psychology, vol.6:4, pp.354-365.

Verma, Kapil \& Joshi, Priyanka. (2015). Casting Couches of Sports in India. The Daily Mail, Online Edition. Retrieved from: http://www.thedailymail.com, on January $25,2013$.

Volkwein, K., Schnell, F., Sherwood, D. \& Livezey, A. (1997). Sexual Harassment in Sport: Perceptions and Experiences of American Female Student-Athletes. International Review for the Sociology of Sport, vol.23:3, pp.283-295. 
Waldron, J., Lynn, Q., Krane V. (2011). Duct Tape, Icy Hot \& Paddles: Narratives of Initiation onto US Male Sport Teams. Sport, Education and Society, vol.16, pp.111-25.

Whelehan, I. (1995). Moderen Feminist Thoughts; from Second Wave to 'Post, Feminism'. United Kingdom Edinburgh University press.

Yorganci, I. (1993). Preliminary Findings from a Survey of Gender Relationships and Sexual Harassment in Sport. In C. Brackenridge (ed), Body matters: Leisure Images and Lifestyle. Eastbourne: Leisure Studies Association.

Yorganci, I. (1994). Gender, Sport and Sexual Harassment. Unpublished doctoral thesis, Chelsea School, University of Brighton.

Shagufta Jahangir is a Ph.D Scholar in the Centre of Excellence for Women's Studies, University of Karachi.

Dr. Asma Manzoor is an Assistant Professor in the Centre of Excellence for Women's Studies, University of Karachi. 